\title{
CORRIGENDUM
}

\section{Production and comprehension} of French wh-questions by children with autism spectrum disorder: A comparative study with specific language impairment-CORRIGENDUM

PHILIPPE PRÉVOST and LAURICE TULLER

Université François Rabelais de Tours

MARIE ANNE BARTHEZ

Tours Regional University Hospital Center

JOËLLE MALVY and FRÉDÉRIQUE BONNET-BRILHAULT

Université François Rabelais de Tours and Clocheville Children's Hospital, Tours

ADDRESS FOR CORRESPONDENCE

Philippe Prévost, UMR Inserm U930, Université François Rabelais de Tours, Tours, France.

E-mail: philippe.prevost@univ-tours.fr

doi:10.1017/S0142716417000078, published by Cambridge University Press, 10 May 2017

The affiliations for the second, third, and fourth authors were incorrect or incomplete, the corrected title page for which is provided herein. We regret these errors and any problems they may have caused.

\section{REFERENCE}

Prevost, P., Tuller, L., Barthez, M. A., Malvy, J., \& Bonnet-Brilhault, F. (2017). Production and comprehension of French $w h$-questions by children with autism spectrum disorder: A comparative study with specific language impairment. Applied Psycholinguistics. Advance online publication. doi: $10.1017 / \mathrm{S} 0142716417000078$ 


\title{
Production and comprehension of French wh-questions by children with autism spectrum disorder: A comparative study with specific language impairment
}

\author{
PHILIPPE PRÉVOST and LAURICE TULLER \\ Université François Rabelais de Tours \\ MARIE ANNE BARTHEZ \\ Clocheville Children's Hospital, Tours
}

\section{JOËLLE MALVY and FRÉDÉRIQUE BONNET-BRILHAULT \\ Université François Rabelais de Tours and Tours Regional University Hospital Center}

Received: March 16, 2016 Accepted for publication: January 15, 2017

\author{
ADDRESS FOR CORRESPONDENCE \\ Philippe Prévost, UMR Inserm U930, Université François Rabelais de Tours, Tours, France. \\ E-mail: philippe.prevost@univ-tours.fr
}

\begin{abstract}
The nature of structural language difficulties in children with autism spectrum disorder (ASD) was explored in a comparative study with specific language impairment (SLI) through investigation of the frequently reported ASD weakness in receptive skills relative to expressive skills. Twenty Frenchspeaking children with ASD aged 6 to 12 were compared to age-matched children with SLI on production and comprehension of $w h$-questions. The two groups displayed similar effects of the complexity of the different $w h$-strategies. In the ASD group (as in the SLI group), these effects were not greater in comprehension compared to production; moreover, nonverbal ability (which varied from normal to impaired) was not related to language performance. Observed ASD-SLI differences are argued to largely be due to ASD pragmatic deficits, rather than to a qualitative difference in structural language skills.
\end{abstract}

Human communication involves linguistic knowledge (grammar, lexicon, and sound structure), as well as knowledge about the context within which it is used (what can be inferred about the speaker's intentions, etc.). This latter type of knowledge, pragmatics, has received considerable attention in studies on autism, and impairment in this domain is considered a core feature of autism spectrum disorder (ASD; see Baron-Cohen, 1988; Boucher, 2003). By contrast, formal aspects of language (those concerning sound, word, and sentence structure) have been

(C) Cambridge University Press 2017 0142-7164/17 